Eur. J. Clin. Chem. Clin. Biochem.

Vol. 29, 1991, pp. 331-337

(C) 1991 Walter de Gruyter \& Co. Berlin - New York

\title{
Comparison of Four Anti-HIV Screening Assays Which Belong to Different Test Generations
}

\author{
By S.-H. Döpel ${ }^{1,2}$, U. Schubert ${ }^{1}$, R. Grunow ${ }^{1}, P$. Pas $^{1}$, W. Rönspeck ${ }^{2}$, G. Pauli ${ }^{3}$ and T. Porstmann ${ }^{1}$ \\ ${ }^{1}$ Department of Medical Immunology, Medical School (Charité), Humboldt University Berlin, Berlin, Germany \\ 2 BIOCHROM KG, Berlin, Germany \\ ${ }^{3}$ Robert-Koch-Institut, Berlin, Germany
}

(Received September 6/December 22, 1990)

Summary: There are three different test generations of enzyme-linked immunosorbent assays (ELISA) for the detection of human immunodeficiency virus (HIV) infection, depending on whether virus lysate, recombinant proteins or synthetic peptides are used as solid phase antigen. Four different assays, i. e., three sandwich ELISAs and one competitive test, were used to demonstrate differences between the three systems with regard to the content of different diagnostically relevant virus proteins. The sensitivities and specificities of these assays were compared by using 312 anti-HIV positive sera and 500 sera of healthy blood donors. The highest sensitivity and specificity were achieved by the competitive ELISA based on recombinant proteins, and by the sandwich ELISA based on synthetic peptides.

\section{Introduction}

The most common screening method for the diagnosis of infection with human immunodeficiency virus (HIV) is the detection of virus-specific antibodies by sandwich ELISA. There are three different test generations, which differ with respect to the insolubilized antigen used:

The assays of the first generation are based on the adsorption of purified lysed virus cultivated in immortalized human lymphocytes. The quantitative ratios between the virus proteins are difficult to repro= duce from one preparation to the other. In addition, diagnostically relevant virus proteins, such as envgene-derived products, are often not available in sufficient quantities (1). On the other hand, host cell proteins incorporated in the virus membrane cannot, or can only incompletely, be removed (2). Antibodies to HLA-DR antigens may therefore produce falsepositive results (3), especially in patients with autoimmune disorders or in multiparae (4). The sensitivity of these tests ranges from $97.2 \%$ to $100 \%$, their specificity from $70 \%$ to $100 \%$ (5).
To circumvent these problems, the assays of the second generation use recombinant proteins as antigen. The composition of the antigen used for insolubilization is now reproducible and can be selected according to the diagnostic relevance of the virus proteins. These proteins, however, require an extensive purification to avoid false positive reactions.

Synthetic peptides used as antigens in third generation tests permit the binding of exclusively specific immunodominant sequences to the solid phase. The reduction of a great number of reactive epitopes of the virus to a few or just one sequence requires a detailed epitope mapping (6). The peptide used in the test has to represent a region, which

(i) induces an antibody response in all HIV-infected persons,

(ii) provokes an antibody response as early as possible,

(iii) maintains the antibody response over all the stages of the disease (7). 


\section{Materials and Methods}

\section{Solid phase}

The tests of the first generation werc performed using commercial microtitre plates of the anti-HTLV III ELISA (Ortho Diagnostic Systems, New Jerscy, USA) and polystyrene microtitre plates (Polyplast, Halberstadt, Germany) coated with purified lysed virus grown in $\mathrm{H} 9$ cells as described in detail elsewhere (8). The same plates ivere also used for the tests of the second and third generations. The respective antigens dissolved in $100 \mu \mathrm{l}$ of $0.1 \mathrm{~mol} / \mathrm{l}$ carbonate buffer, $\mathrm{pH} 9.5$, were added to each well for adsorption over $16-20 \mathrm{~h}$ al $4{ }^{\circ} \mathrm{C}$.

The antigens used in the second test generation were two highly purified recombinant env-proteins of HIV-1. For the competitive test wc used a glycosylated gp160 expressed in verocells (Immuno-AG, Vienna, Austria) adjusted to a concentration of $10 \mathrm{mg} / \mathrm{l}$. For the sandwich ELISA, the solid phase was coated with $20 \mathrm{mg} / \mathrm{l}$ of a $\beta$-galactosidase-gp41 (usion protein expressed in E. coli (rlacZgp41) (Schubert et al.. in preparation).

The peptide used as antigen in the third generation assay corresponds to the sequence aa 595-620 of the transmembrane protein gp 41 of HIV-1. For adsorption, the peptide was used in a concentration of $10 \mathrm{mg} / \mathrm{l}$. After coating, free binding sites of the solid phase were blocked with sheep serum $(200 \mathrm{ml} / \mathrm{l})$ in $0.01 \mathrm{~mol} / 1$ phosphate buffer, $0.15 \mathrm{~mol} / 1 \mathrm{NaCl}$ for $60 \mathrm{~min}$ at room temperature. Prior to use, all coated plates were washed twice with $0.01 \mathrm{~mol} / \mathrm{l}$ phosphate buffer, $\mathrm{pH} 7.2,0.3 \mathrm{~mol} / 1 \mathrm{NaCl}$, $1 \mathrm{ml} / \mathrm{l}$ Tween 20.

The aim of this study was to determine the degree of certainty for the detection of HIV infection, using different assay principles and different solid phase antigens containing an immunodominant region of the transmembrane protein gp41. Other parameters influencing the assay quality were optimized for each assay.

Quantitative solid-phase analysis of several gene products

Plates of the first generation test were analysed for their relative content of 5 selected env- and gag-gene products. Polyclonal antisera from sheep to the HIV-1 proteins 15 , p17, p24, gp41 and gp120 (Biochrom KG, Berlin) were applied in twofold serial dilutions, starting with a concentration of $20 \mathrm{mg} / \mathrm{l}$, to detect the bound proteins. The dilution medium used in all the steps of the assays was phosphate/ $\mathrm{NaCl} /$ Tween, $100 \mathrm{ml} / \mathrm{l} \mathrm{Ge}$ lafusal (Serumwerk, Bernburg). One hundred $\mu$ l of the different dilutions were incubated in the virus-sensitized wells for $1 \mathrm{~h}$ at $37^{\circ} \mathrm{C}$.

After this incubation, the wells were washed five limes with phosphate $/ \mathrm{NaCl} / \mathrm{Tw}$ wen to remove any unbound reagents. One hundred $\mu \mathrm{l}$ of horseradish peroxidase-labelled anti-sheep IgG adjusted to an $\mathrm{IgG}$ concentration of $0.3 \mathrm{mg} / \mathrm{l}$ were added to the wells and incubated for $1 \mathrm{~h}$ at $37^{\circ} \mathrm{C}$.

After a further washing, the substrate reaction was performed using $100 \mu \mathrm{l}$ of $5.5 \mathrm{mmol} / \mathrm{l} o$-phenylenediamine and $8.5 \mathrm{mmol} / \mathrm{l}$ $\mathrm{H}_{2} \mathrm{O}_{2}$ in $0.1 \mathrm{~mol} / \mathrm{l}$ citrate buffer, $\mathrm{pH} 5.0$. This reaction was stopped after $10 \mathrm{~min}$ by addition of $100 \mu \mathrm{l}$ of $2 \mathrm{~mol} / 1 \mathrm{H}_{2} \mathrm{SO}_{4}$, $0.05 \mathrm{~mol} / \mathrm{l}$ sodium sulphite. The absorbances were read bichromatically at $492 \mathrm{~nm}$ and $690 \mathrm{~nm}(10)$.

The relative quantity of the selected virus proteins adsorbed to the solid phase was expressed as a percentage of maximal adsorption at saturation, as determined from the maximal absorbance values of the ELISA titration curves.

Quantitative solid phase analysis of an immunodominant epitope

The solid phases coated with the different antigens were examined for the presence of a diagnostically relevant immuno- dominant region of the transmenbranc protein gp41 (aa 606620 ). This region is the binding site of the human monoclonal antibody CB-HIV-1-gp41 (9), which was applied on twofold serial dilutions starting with a concentration of $20 \mathrm{mg} / \mathrm{l}$. The antibody solutions were incubated for $1 \mathrm{~h}$ at $37{ }^{\circ} \mathrm{C}$ in the coated wells. After the solid phase had been washed five times with phosphate/ $\mathrm{NaCl} / \mathrm{Tween}$, an horseradish peroxidase-labelled anti-human IgG adjusted to an IgG concentration of $0.05 \mathrm{mg} /$ $\mathrm{l}$ was incubated for $1 \mathrm{~h}$ at $37^{\circ} \mathrm{C}$. Unbound reagents were removed by washing. After the substrate reaction, the absorbances were read as described above.

\section{Serum reactivity}

To document the relationship of the absorbance values produced in the ELISAs by reactive and non-reactive serum samples $(\mathrm{P} / \mathrm{N}$ ratio), titrations were performed on anti-HIV positive $(\mathrm{n}=20)$ and anti-HIV negative $(\mathrm{n}=20)$ pooled serum samples, using twofold serial dilutions, and starting with the undiluted serum. One hundred $\mu$ l of these samples were incubated in the wells of all the test systems for $1 \mathrm{~h}$ at $37^{\circ} \mathrm{C}$. The wells were washed, and the horseradish peroxidase-labelled anti-human $\operatorname{IgG}(0.05 \mathrm{mg} / \mathrm{l})$ was incubated for $1 \mathrm{~h}$ at $37^{\circ} \mathrm{C}$.

\section{Sandwich ELISA of the first generation}

For the first generation test developed in our laboratory, $55 \mu \mathrm{l}$ of the 1:51 diluted serum samples were incubated for $1 \mathrm{~h}$ at $37^{\circ} \mathrm{C}$ followed by five washes and a $1 \mathrm{~h}$ incubation of $100 \mu \mathrm{l}$ horseradish peroxidase labelled anti-human IgG (IgG: $0.2 \mathrm{mg} / \mathrm{l}$ ) per well at $37^{\circ} \mathrm{C}$. Another washing was followed by a $30 \mathrm{~min}$ substrate reaction.

\section{Sandwich ELISA of the second generation}

The sandwich principle was also applied in the test of the second generation, using the purified, insolubilized, recombinant rlacZgp41 protein. One hundred $\mu$ of the $1: 150$ diluted serum samples were incubated for $1 \mathrm{~h}$ at $37^{\circ} \mathrm{C}$. After washing the plates five times with phosphate $/ \mathrm{NaCl} / \mathrm{Tween}$, an horseradish peroxidase-labelled anti-human IgG adjusted to an IgG concentration of $0.05 \mathrm{mg} / \mathrm{l}$ was incubated for $1 \mathrm{~h}$ at $37^{\circ} \mathrm{C}$. This was followed by a $15 \mathrm{~min}$ reaction with the above-described substrate solution.

\section{Competitive ELISA of the second generation}

In this assay, antibodies to an immunodominant region of the transmembrane protein gp41 of HIV-1 in the serum of HIVinfected persons inhibit the binding of the horseradish peroxidase-labelled human monoclonal antibody CB-HIV-1-gp41 to the insolubilized recombinant gp 160 protein (11). Twenty five $\mu l$ of the undiluted serum samples were incubated for $45 \mathrm{~min}$ at $37^{\circ} \mathrm{C}$ with $75 \mu \mathrm{l}$ of the horseradish peroxidase-labelled mono= clonal antibody adjusted to a concentration of $6.5 \mathrm{mg} / \mathrm{l}$. The wells were washed five times with phosphate $/ \mathrm{NaCl} / \mathrm{Tween}$, followed by a $10 \mathrm{~min}$ substrate reaction.

\section{Sandwich ELISA of the third generation}

One hundred $\mu \mathrm{l}$ of the $1: 10$ diluted serum samples were incubated in the peptide-coated wells for $1 \mathrm{~h}$ at $37^{\circ} \mathrm{C}$. After incubation the wells were washed five times and the anti-human IgG-horseradish peroxidase conjugate, adjusted to a concentration of $0.05 \mathrm{mg} / \mathrm{l}$, was added and incubated for $1 \mathrm{~h}$ at $37^{\circ} \mathrm{C}$. Another washing was followed by a $10 \mathrm{~min}$ substrate reaction.

\section{Serum samples}

Three hundred and twelve anti-HIV-1 positive serum samples from HIV-1 infected persons at all stages of the disease (CDC 
classification II - IV), including 200 serum samples from AIDS patients (partially treated with azidothymidine), and 500 sera from anti-HIV negative healthy blood donors were investigated. The serum samples were kindly provided by five different clinical or screening centres. All the anti-HIV positive sera werc confirmed by immunoblotting.

\section{Statistical methods}

For each test system the cut-ofr value was defined as the mean value derived from at least 100 anti-HIV negative samples plus the threefold standard deviation (SD). In presenting the results of the competitive assay, a value equivalent to $3 \times \mathrm{SD}$ was subtracted.

The sensitivity of each test system is defined as the proportion of positive test results obtained when a population of true positives is tested, and the specificity of each test system as the frequency of negative results obtained when a population of true negatives is tested.

Samples that gave false negative and false positive results in the ELISAs were retested by immunoblotting.

\section{Results}

\section{Epitope analysis and serum reactivity}

The relative quantity of reactive env- and gag-gene products of the solid phase adsorbed virus proteins is shown in figure 1 . The ratio of the immunologically reactive gag-to env-gene products is about $6: 1$.
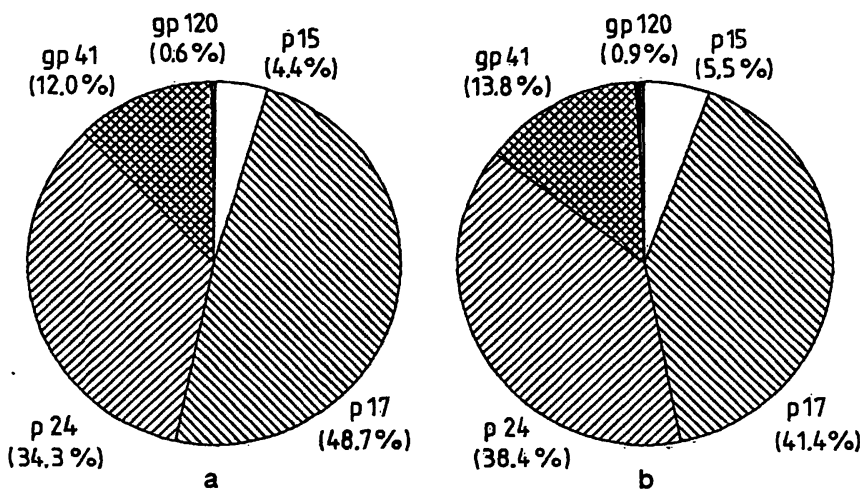

Fig. 1. Relative proportion of 5 gag- and env-proteins adsorbed to the solid phases in the anti-HTLV-III ELISA (Ortho Diagnostic Systems) (Part A) and in the self-made antiHIV ELISA (Part B) on the solid phase adsorbed proteins.

Curves for the titration of the human monoclonal antibody, CB-HIV-1-gp41, to the immunodominant region of the transmenbrane protein gp41 of HIV-1 with the respective insolubilized antigens is shown in figure 2 . The absorbance plateaus, which reflect the excess of antibodies available for binding to the limited quantity of gp41 of the respective insolubilized antigen, characterize the different epitope density on the solid phase. Insolubilization of the peptide (amino acids 959-620) led to the highest epitope density; the next highest epitope density was found for the inso-

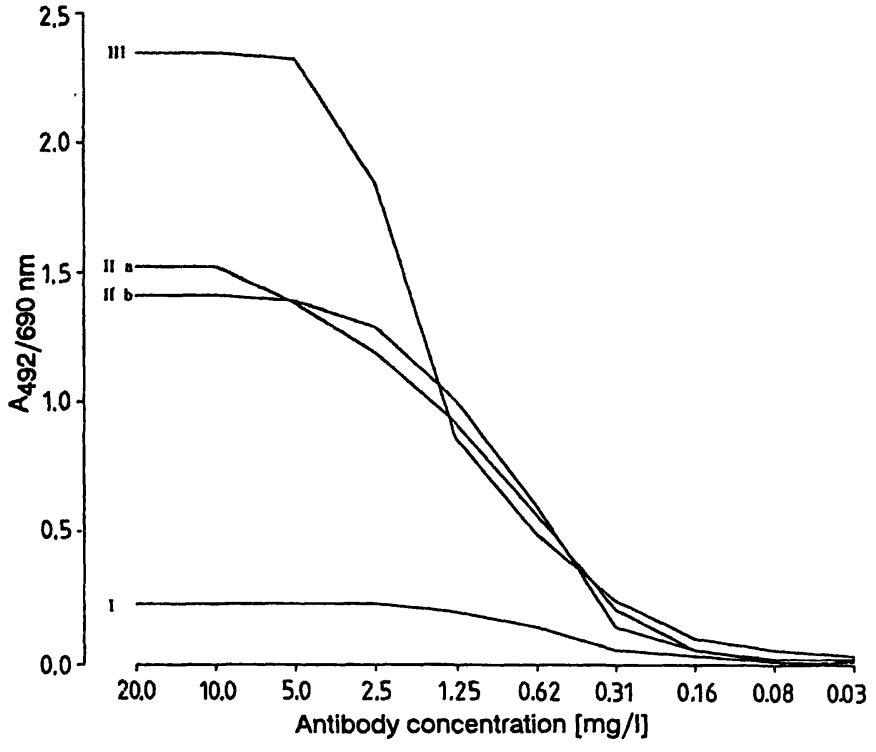

Fig. 2. Titration curves of a human monoclonal antibody in first (I), second (II a: rlacZgp41; II b: rgp160) and third (III) generation tests.

The different absorbance plateaus are representative for the limited quantity of the immunodominant transmembrane protein, gp41, in each test system.

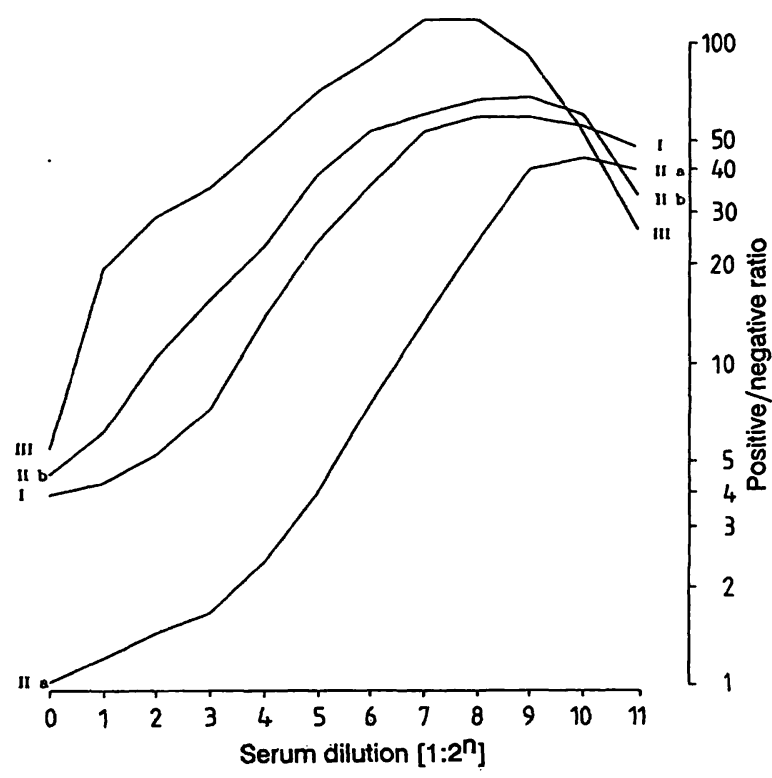

Fig. 3. Dependence of $P / N$ ratio on the serum dilution; relation of serum reactivity of the anti-HIV-positive and -negative pooled sera $(n=20)$ in the first $(I)$, second (II a: rlacZgp41; II b: rgp160) and third (III) generation tests.

lubilized recombinant antigens. As deduced from the absorbance values, the relative quantity of reactive epitopes from this region of the transmembrane protein in the absorbed virus lysate is no greater than $8 \%$ and in the adorbed recombinant proteins $60 \%$ of the adsorbed peptide epitope density (100\%).

Figure 3 shows the $\mathrm{P} / \mathrm{N}$ ratios obtained from testing the anti-HIV-positive and -negative pooled sera, depending on their dilutions. 

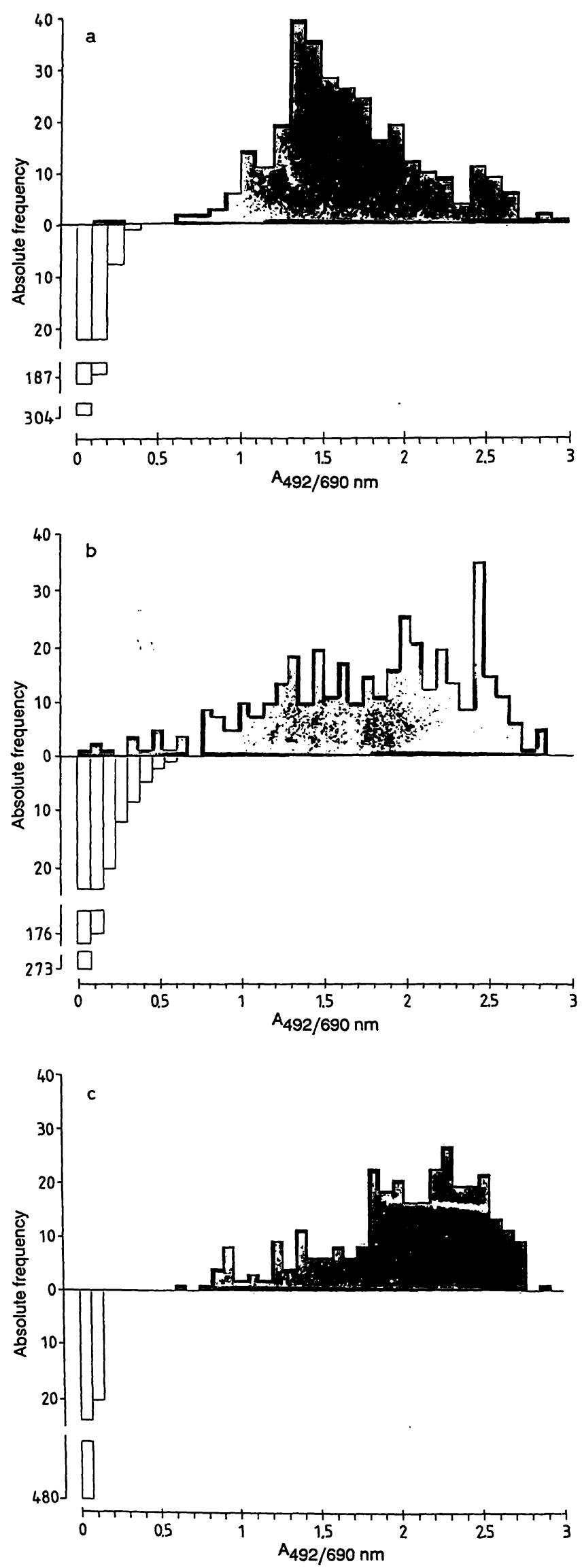

Fig. 4. Frequency distribution of the absorbances produced by 312 anti-HIV-positive (black) and 500 negative (white) serum samples in the sandwich-type ELISA of the first generation with virus lysate (a), of the second generation with purified recombinant rlacZgp41-protein (b) and of the third generation with peptides (c).
The increase in $\mathrm{P} / \mathrm{N}$ ratios with growing serum dilution is due to reduced unspecific binding of human $\mathrm{IgG}$ from the serum samples. The extent of unspecific IgG binding of anti-HIV-negative serum samples clearly depends on the antigen used for solid phase adsorption. Thus a 30-fold serum dilution resulted in a $\mathrm{P} / \mathrm{N}$-ratio of about 30 when the gp41 peptide was used as the solid phase antigen in the sandwich ELISA. Using purified recombinant gp41 protein as solid phase antigen in the same assay, a $\mathrm{P} / \mathrm{N}$ ratio of about 30 was obtained with a 250 -fold serum dilution.

\section{Serum testing}

The frequency distributions of the absorbances of the anti-HIV-positive and -negative serum samples, as determined in the three different sandwich ELISAs, are shown in figure 4.

The clearest differentiation was obtained in the third generation assay, using insolubilized peptide.

The second generation sandwich ELISA does not allow an unequivocal differentiation of the two groups of serum samples. Using the chosen cut-off value, 8 serum samples were determined as false positive and 9 as false negative, as deduced from the Western blot results.

The competitive test of the second generation also clearly discriminated between the anti-HIV antibodypositive and -negative sera (fig. 5).

Two of the anti-HIV-positive sera, which did not react in the first-generation sandwich ELISA, proved to be unequivocally positive in the immunoblot (fig. 6). The absorbances of these two sera produced in the different tests are listed in table 1.

The cut-off values, the sensitivity and the specificity of each of the four test systems are shown in table 2.

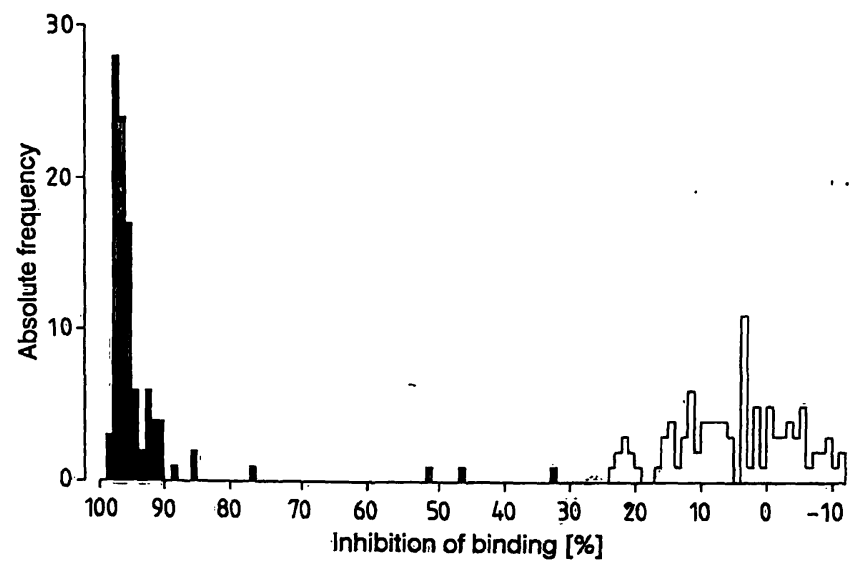

.Fig. 5. Inhibition of binding of 102 anti-HIV-positive (black) and -negative (white) serum, samples in a competitive assay of the second generation. 


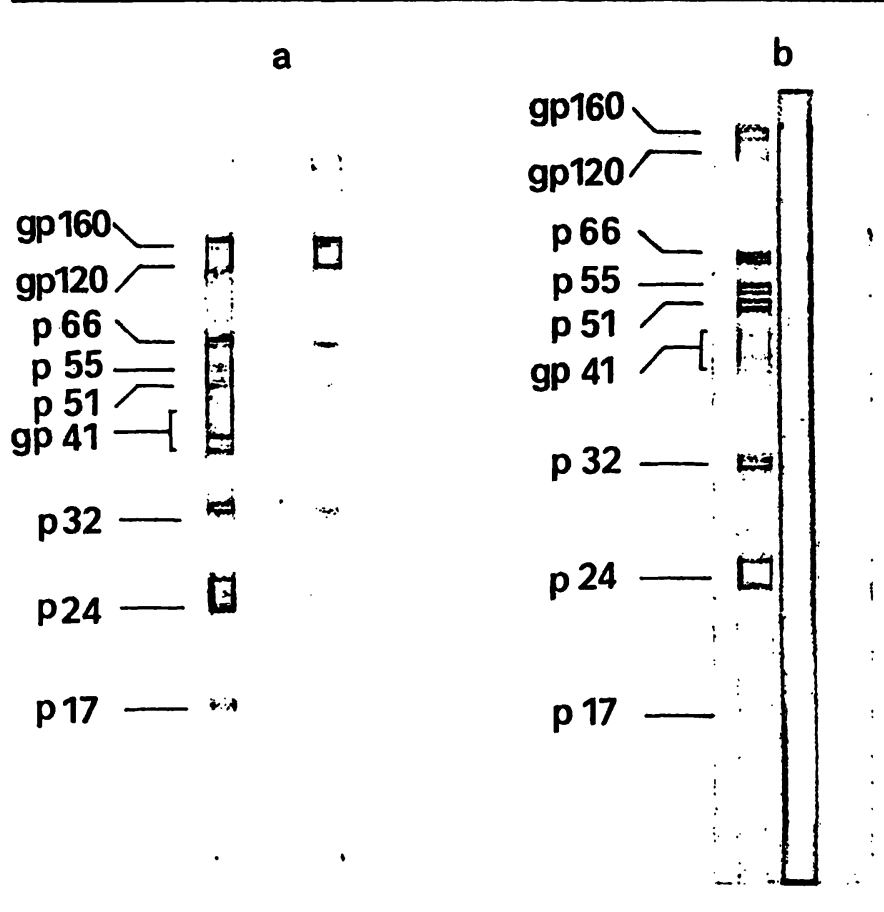

Fig. 6. Western blot precipitation patterns of serum samples from an early phase of infection from two asymptomatic HIV-infected persons $(6 a$ - serum $124 ; 6 b$ - serum 293).

The left lanes in $a$ and $b$ are the respective positive controls.

Tab. 1. Single determinations of two anti-HIV-positive sera in the four test systems

\begin{tabular}{llll}
\hline Test & Cut-off & Serum 124 & Serum 293 \\
\hline $\begin{array}{l}\text { First } \\
\text { generation }\end{array}$ & $\begin{array}{l}0.42 \\
\text { (absorbance) }\end{array}$ & $\begin{array}{l}0.257 \\
\text { (negative) }\end{array}$ & $\begin{array}{l}0.184 \\
\text { (negative) }\end{array}$ \\
$\begin{array}{l}\text { Second } \\
\text { generation }\end{array}$ & $\begin{array}{l}0.40 \\
\text { (absorbance) }\end{array}$ & $\begin{array}{l}0.460 \\
\text { (positive) }\end{array}$ & $\begin{array}{l}0.329 \\
\text { (negative) }\end{array}$ \\
$\begin{array}{l}\text { Third } \\
\text { generation }\end{array}$ & $\begin{array}{l}0.35 \\
\text { (absorbance) }\end{array}$ & $\begin{array}{l}0.811 \\
\text { (positive) }\end{array}$ & $\begin{array}{l}0.637 \\
\text { (positive) }\end{array}$ \\
$\begin{array}{l}\text { Competitive } \\
\text { assay }\end{array}$ & $\begin{array}{l}30 \% \\
\text { (inhibition) }\end{array}$ & $\begin{array}{l}\text { 92.4\% } \\
\text { (positive) }\end{array}$ & $\begin{array}{l}97.3 \% \\
\text { (positive) }\end{array}$ \\
\hline
\end{tabular}

Tab. 2. Cut-off values, sensitivity and specificity of the four test systems

\begin{tabular}{llcc}
\hline Test & Cut=off & Specificity & Sensitivity \\
\hline $\begin{array}{l}\text { First } \\
\text { generation }\end{array}$ & $\begin{array}{l}0.42 \\
\text { (absorbance) }\end{array}$ & $100 \%$ & $99.4 \%$ \\
$\begin{array}{l}\text { Seçond } \\
\text { generation }\end{array}$ & $\begin{array}{l}0.40 \\
\text { (absorbance) }\end{array}$ & $98.4 \%$ & $97.2 \%$ \\
$\begin{array}{l}\text { Third } \\
\text { generation }\end{array}$ & $\begin{array}{l}0.35 \\
\text { (absorbance) }\end{array}$ & $100 \%$ & $100 \%$ \\
$\begin{array}{l}\text { Competitive } \\
\text { assay }\end{array}$ & $\begin{array}{l}30 \% \\
\text { (inhibition) }\end{array}$ & $100 \%$ & $100 \%$ \\
\hline
\end{tabular}

\section{Discussion}

Env-gene products of HIV induce an immune response preceding that to gag-gene products (12). In contrast to the latter response, the immune response to env-gene products of HIV remains relatively constant up to the stage of AIDS (CDC, stage IV) (13, $14,15)$. For this reason, tests employing a preferential detection of antibodies to env-proteins are more sensitive (16). The quantities of these diagnostically relevant proteins used in the solid phase of the first generation assays are generally too low. The composition of HIV proteins was very similar in both kinds of investigated ELISA plates that use adsorbed purified virus used as antigen. But the content of the envgene products in relation to the total amount of insolubilized virus proteins is less then $15 \%$, as shown by the fact that pol-gene derived products were not detected in the investigations described due to a lack of antibodies to reverse transcriptase and protease.

The human monoclonal antibody, CB-HIV-1-gp41, was found to recognize an immunodominant region on the transmembrane protein, gp41 (17). Investigations with this antibody have shown that the density of its target epitope can be systematically increased from the first to the third generation assay.

This is also the reason for the different reactivities of the two serum samples, which were clearly positive in the sandwich ELISA only when peptide is used as solid phase antigen. This result is in excellent agreement with their precipitation profile in the Western blot. Both samples reacted poorly with the gag-genederived proteins, $\mathrm{p} 17$ and $\mathrm{p} 24$, representing the majority of solid phase-adsorbed proteins in the first generation assay.

The $\mathrm{P} / \mathrm{N}$ ratios of the screening ELISAs, depending on the serum dilution, are of prime importance for their specificity and sensitivity. A high $\mathrm{P} / \mathrm{N}$-ratio of low serum dilutions was obtained only when peptides were used as solid phase antigen. In the case of adsorbed virus lysate or recombinant proteins, undesirable reactions of IgG with co-immobilized host-cell or host-bacterial compounds decreased the $\mathrm{P} / \mathrm{N}$-ratio. The insufficient sensitivity and specificity of the sandwich ELISA based on the recombinant protein is due to the insufficient purification of the gp41 protein, which still contains material that reacts with anti-E. coli antibodies present in the serum of blood donors. By dilution sera in medium containing $E$. coli lysate, it was shown unequivocally that positive results can be caused by antibodies to $E$. coli (data not shown). Even highly purified recombinant proteins contain epitopes likely to react with IgG molecules which are not directly involved in the immune response to HIV 
(15). Thereforc, first and second generation tests are recommended for higher serum dilutions if no competitive assay principle is applied.

The numbers of 312 anti-HIV antibody-positive and of 500 anti-HIV antibody-negative sera are certainly insufficient for a comprehensive evaluation of the sensitivity and the specificity. Nevertheless, advantages and disadvantages of the individual assay variants and the solid-phase materials used can easily be seen from the data presented here.

In our experiments, the best differentiation between the anti-HIV-positive and -negative serum samples was achieved with the peptide ELISA based on only one peptide, which agrees with the results reported by Smith et al. (18). Although this peptide represents a highly conserved immunogenic region (7), geographic variability, especially in proteins encoded by the env-gene, has been shown by genetic studies (19) on this region of the transmembrane protein. This is

\section{References}

1. Allan, J. S., Colligan, J. E., Lee, T. H., Mc Lane, M. F., Kanki, P. J., Groopman, J. E. \& Essex, M. (1985) A new HTLV-III/LAV antigen detected by antibodies from AIDS patients. Science 230, 1091-1094.

2. Hoxie, J. A., Fitzharris, T. P., Youngbar, P. R., Mattews, D. M., Ruckowski, J. L. \& Radka, S. F. (1987) Nonrandom association of cellular antigens with HTLV-III virions. Human Immunol. 18, 39-52.

3. Gelderblom, H., Özel, M., Hausmann, E. \& Pauli, G. (1986) Feinstruktur und antigener Aufbau des Humanen Immunodeficiency Virus (HIV). Bundesgesundhbl. 29, 376-382.

4. Kühnl, P., Seidl, S. \& Holzberger, G. (1985) HLA DR4 antibodies cause positive HTLV-III antibody ELISA results. Lancet $I, 1222-1223$.

5. Gürtler, L. G., Eberle, J., Lorbeer, B. \& Deinhardt, F. (1986) Sensitivity and specificity of commercial ELISA kits for screening anti-LAV/HTLV-III. J. Virol. Methods 15, 11.

6. Modrow, S., Hahn, B. H., Shaw, G. M., Gallo, R. C., Wong-Staal, F. \& Wolf, H. (1988) Computer-assisted analysis of envelope protein sequences of seven Human Immunodeficiency Virus isolates: Prediction of antigenic epitopes in conserved and variable regions. J. Virol. 61, 570578.

7. Döpel, S.-H., Porstmann, T., Henklein, P. \& van Baehr, R. (1990) Fine mapping of an immunodominant region of the transmembrane protein of the Human Immunodeficiency Virus (HIV-1). J. Virol. Methods 25, 167-178.

8. Porstmann, T., Porstmann, B., KieBig, S. T., Nugel, E., Scholz, D., Grunow, R., Volk, H.-D., Ladboff, A. \& v. Baehr, R. (1987) Diagnostik und Verlaufskontrolle von Infektionen mit dem humanen Immundefizienzvirus (HIV). Med. Aktuell 13, 448-450.

9. Grunow, R., Jahn, S., Porstmann, T., Kiessig, S. T., Steinkellner, H., Steindl, F., Mattanovich, D., Gürtler, L., Deinhardt, F., Katinger, H. \& von Baehr, R. (1988) The highefficiency, human $\mathrm{B}$ cell immortalizing heteromyeloma $\mathrm{CB}$ F7. J. Immunol. Methods 106, 257-604. reflected by different reactivities of serum samples to peptides which differ in only one amino acid (20). However, the low molecular mass and the high epitope density permit a co-immobilization of different peptides even together with complete proteins such as antibodies, so that different parameters can be selectively determined in one and the same assay (21).

\section{Acknowledgement}

The purified recombinant gp 160 protein was kindly provided by Prof. Dorner (Immuno-AG, Vienna, Austria).

We wish to thank Professor F. Deinhardt, Max-von-PettenkoferInstitut of the Ludwig Maximilian University Munich, and Professor K. O. Habermehl, Institute of Experimental and Clinical Virology, Free University Berlin, for providing some of the anti-HIV positive sera.

The non-reactive sera tested by anti-HIV ELISA were kindly provided by Professor G. Fünfhausen, Blood Transfusion Service Berlin.
10. Porstmann, T., Porstmann, B., Wietschke, R., von Baehr, R. \& Egger, E. (1984) Stabilization of the substrate reaction of horseradish peroxidase with 0 -phenylenediamine in the enzyme immunoassay. J. Clin. Chem. Clin. Biochem. 23, $41-44$.

11. Döpel, S.-H., Porstmann, T., Grunow, R., Jungbauer, A. \& von Baehr, R. (1989) A human monoclonal antibody used in a rapid competitive anti-HIV ELISA. J. Immunol. Methods 116, 223-233.

12. Saah, A. J., Farżadegan, H., Fox, R., Nishanian, P., Rinaldo, Ch. R., Phair, J. P., Fahey; J. L., Lee, T.-H. \& Polk, B. F. (1987) Detection of early antibodies in human immunodeficiency virus infection by enzyme-linked immunosorbent assay, westernblot and radioimmunoprecipitation. J. Clin. Microbiol. 25, 1605-1610.

13. Goudsmit, J., Paul, D. A., Lange, J. M. A., Speelman, H., van der Noordaa, J., van der Helm, H. J., de Wolf, F., Epstein, L. G., Krone, W. J. A., Wolters, E. Ch., Oleske, J. M. \& Coutinho, R. A. (1986) Expression of human immunodeficiency antigen ( $\mathrm{HIV}-\mathrm{Ag}$ ) in serum and cerebrospinal fluid during acute and chronic infection. Lancet $I I$, $177-180$.

14. Goudsmit, J., Boucher, C. A. B., Meloen, R. H., Epstein, L. G., Smit, L., van der Hoek, L. \& Bakker, M. (1988) Human antibody response to a strain-specific HIV-1 gp120 epitope associated with cell fusion inhibition. AIDS 2, 157-164.

15. Modrow, S., Höflacher, B., Mellert, W., Erfle, V., Wahren, B. \& Wolf, H. (1989) Use of synthetic oligopeptides in identification and characterization of immunological functions in the amino acid sequence of the envelope protein of HIV-1. Journal of Acquired Immune Defieiency Syndromes 2, 21-27.

16. Schneider, J., Wendler, I., Guillot, F., Hunsmann, G., Gạllati, H., Schoenfeld, H.-J., Stüber, D. \& Mous, J. (1987) A new ELISA test for HIV antibodies using a bacterially produced viral env gene product. Med. Microbiol. Immunol. 176, $47-51$. 
17. Döpel, S.-H., Porstmann, T., Grunow, R., Henklein, P., Pas, P. \& von Bachr, R. (1990) Binding behaviour of specifically reacting antibodies to an immunodominant region of the transmembrane protein gp 41 of the HIV-1. J. Virol. Methods 28, 189-198.

18. Smith, R. S., Naso, R. B., Rosen, J., Whalley, A., Hom, Y.-L., Hoey, K., Kennedy, C. J., McCutchan, J. A., Spector, S. A. \& Richman, D. D. (1987) Antibody to a synthetic oligopeptide in subjects at risk for HIV infection. J. Clin. Microbiol. 25, $1498-1504$.

19. Hahn, B. H., Gonda, M. A., Shaw, G. M., Popovic, M., Hoxie, J. A., Gallo, R. C. \& Wong-Stahl, F. (1985) Genomic diversity of the acquired immune deficiency virus HTLV III: Different viruses exhibit greatest divergence in their envelope genes. Proc. Natl. Acad. Sci. USA 82, 48134817.
20. Gnann, J. W., McCormick, J. B., Mitchell, S., Nelson, J. A. \& Oldstone, M. B. A. (1987) Synthetic peptide immunoassay distinguishes HIV type 1 and HIV type 2 infections. Science 237, 1346-1349.

21. Porstmann, T., Nugel, E., Döpel, S.-H., Porstmann, B., Pas, P., Frenzel, B., and von Baehr, R. A new ELISA for simultaneous but differentiated detection of HIV and HBV infections (in preparation).

Dr. Sven-Holger Döpel

BIOCHROM KG

Leonorenstraße 2-6

W-1000 Berlin 46

Bundesrepublik Deutschland 
